\title{
JUURNAL.RU
}

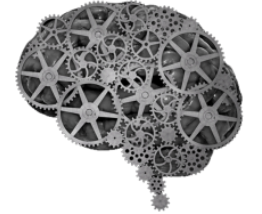

COMPANY GROUP "INTELLEKT"

\author{
Мовсесян Б.В., Чучулина А.В. \\ Северо-Кавказский федеральный университет
}

doi: 10.18411/1j2016-5-2-18

\section{Современные направления и формы финансирования реального сектора экономики}

Сегодня адекватные и действенные формы финансирования в реальный сектор экономики определяют эффективность развития страны в целом, но ситуация, сложившаяся в финансовой системе России оценивается многими независимыми специалистами-аналитиками далеко неоднозначно. С одной стороны, в стране накоплены значительные золотовалютные запасы (нефтедоллары), по объему которых Россия находится в пятерке мировых ведущих держав (Таблица 1), позволяющие обеспечить финансовую устойчивость российской экономики, относительную стабильность управления хозяйственными процессами в кризисные периоды.

С другой стороны - растущая отсталость социального, научнотехнического, инновационного комплексов экономики, спровоцированная высокой коррумпированностью экономики, при которой теневой оборот финансов составляет чуть ли не половину ВВП страны, что привело к переориентации экономики с инновационной на сырьевую, формирующую финансовые ресурсы за счет распродажи невозобновляемого потенциала страны. Нестабильная мировая ситуация, спровоцированная постоянными экономическими кризисами, привела к резким колебаниям российского финансового рынка, что не могло не отразиться на финансировании реального сектора экономики. 
Список стран по золотовалютным резервам по даннымм МВФ на 2016 год, млн. долларов

\begin{tabular}{|c|c|c|}
\hline № & Страна & Резерв, млн. долл. \\
\hline 1 & США \\
\hline 2 & КНР & 3294002 \\
\hline 3 & Саудония & 1248107 \\
\hline 4 & Швейцария & 562658 \\
\hline 5 & Россия & 618702 \\
\hline
\end{tabular}

Таким образом, вопросы расширения и совершенствования направлений финансирования реального сектора экономики приобретают особую актуальность на современном этапе.

В экономической литературе под реальным сектором экономики подразумевается комплекс отраслей, который производит материальные и нематериальные блага, за исключением денежно-финансовых операций.

Эффективность деятельности реального сектора экономики в настоящее время трудно представить без привлечения заемного капитала. Это оправдывается невысокой (по сравнению с финансовым сектором) рентабельностью, длительными сроками окупаемости, что затрудняет применение только собственных средств в деятельности хозяйствующих субъектов.

Поэтому одним из направлений финансирования реального сектора экономики было и остается кредитование бизнеса. Как говорилось выше, нестабильность финансовых рынков привела к скачку процентных ставок по кредитам для предприятий реального сектора экономики. В конце 2014 года ключевая ставка увеличилась до 17\%. Была проведена плодотворная работа по уменьшению процентной ставки и 3 августа 2015 года Советом директоров Банка России было принято решение о снижении ключевой ставки до $11 \%$. Главное следствие от снижения ключевой ставки - это снижение процентов по кредитам, оно должно позволить улучшить ситуацию с доступностью кредитов 
для реального сектора экономики. Работа по уменьшению процентной ставки повлияет на объем привлекаемых ресурсов предприятиями и организациями, что станет важным инструментом денежно-кредитной политики в вопросах финансирования реального сектора экономики и увеличит ее ликвидность. Через канал процентной ставки обеспечится воздействие денежной политики властей как на объемы кратко-, средне- и долгосрочного кредитования, так и на основные макроэкономические результаты деятельности хозяйствующих субъектов.

Одним из направлений финансирования реального сектора экономики можно назвать деятельность фондового рынка, который выполняет ряд функций в данном вопросе:

- аккумулирует временно свободные финансовые ресурсы, трансформируя в последующем в инвестиционный капитал;

- перераспределяет капитал между областями экономики;

- формирует ликвидность;

- перераспределят риска.

Одной из проблемных функций фондового рынка является «перераспределительная». Эффективность аккумулирования финансовых ресурсов с последующей трансформацией их в инвестиции в реальный сектор экономики, находится постоянно в центре множества дискуссий.

Единого мнения по данному вопросу пока нет. Такие исследователи, как Н.Б. Козлов, Я.М. Миркин, Р.В. Федоров и др., придерживаются мнения, что российский фондовый рынок не выполняет поставленных задач по адекватному перераспределению ресурсов в реальный сектор и его взаимодействие с ним явно недостаточное.

Ю.А. Данилов, В.Р. Евстигнеев, В.А. Иванюк, И.А. Тарасова, М.К. Осипова и др. придерживаются взглядов на то, что российский фондовый рынок прошел период становления и стабилизации, что позволяет ему эффективно работать с инвестиционными ресурсами, отправляя их в реальный сектор. 
Также существует компромиссная точка зрения, основывающаяся на том, что российский фондовый рынок сформировал потенциальный ресурс для реализации «перераспределительной функции», но этот потенциал слабо используют субъекты реального сектора экономики в связи со слабостью корпоративного управления и непрозрачности финансовой отчетности предприятий [1, с. 10].

Кризисные явления в экономике негативно сказались на интеграции фондового рынка в реальный сектор экономики. За последние 3-4 года существенно увеличился вывоз экономическими агентами капитала за границу и вкладывание его в зарубежные активы, что позволяет говорить о «бегстве» капитала из России, т.е. быстром перемещении достаточно серьезных объемов краткосрочных заемных капиталов за рубеж, в частности, данный показатель в 2014 году составил более 150 млрд. долл. [2, с. 223].

Также негативно кризисные явления сказались на относительных масштабах присутствия фондового рынка в реальном секторе экономики. Развитие фондового рынка показывает более низкие показатели относительного масштаба по сравнению с успешно развивающимися странами. Показатель относительного масштаба финансового рынка в России не достигает и $150 \%$, тогда как в развивающихся странах он достигает 250\%, а в развитых - 300-350\%.

Аналитики считают, что для осуществления долгосрочного экономического роста привлекаемые в реальный сектор отечественные и иностранные инвестиции должны обеспечивать прирост чистых инвестиций. При этом увеличение капитализации фондового рынка само по себе не станет причиной возникновения эффективного инвестиционного механизма. Необходимо учесть качественные изменения фондового рынка, что, в свою очередь, требует изменений в самой структуре российской экономики.

Для решения стратегических вопросов повышения эффективности финансирования реального сектора экономики, одним из наиболее важных направлений является восстановления и развития инвестиционной активности. 
Необходимо создание новых финансовых инструментов, прежде всего государственного участия в инвестировании крупных инфраструктурных проектов.

Правительством РФ в 2015 году сформулирован и утвержден перечень первоочередных мероприятий, обеспечивающих устойчивое развитие реального сектора экономики и социальной стабильности в период неблагоприятной внешнеэкономической и внешнеполитической обстановки. Ключевым направлением в данной программе стало импортозамещение.

К мерам финансовой поддержки реального сектора экономики были отнесены:

- формирование механизма предоставления из федерального бюджета предприятиям промышленности, реализующим проекты импортозамещения, субсидий на компенсацию части затрат на уплату процентов по кредитам, привлеченным в российских кредитных организациях на пополнение оборотных средств и (или) финансирование текущей производственной деятельности;

- компенсация расходов гражданам, связанных с изменением валютного курса при приобретении импортных лекарственных средств, медицинских изделий и расходных материалов;

- совершенствование системы предоставления государственных гарантий Российской Федерации в целях поддержки экспорта: упрощение условий и процедур предоставления государственных гарантий Российской Федерации в иностранной валюте для оказания государственной поддержки экспорта промышленной продукции [3, c. 78].

В долгосрочные стратегические планы финансовой поддержки были включены следующие мероприятия:

- создание института проектного финансирования, обеспечивающего для субъектов наиболее важных секторов экономики комфортные 
правила кредитования в условиях закрытия глобальных рынков капитала;

- совершенствование нормативно-правовой среды функционирования субъектов экономической деятельности, в целях предоставления российским товаропроизводителям приоритетного права насыщения внутреннего рынка;

- восстановление и развитие инвестиционной активности в экономике;

- применение сбалансированного валютного курса, направленного на адекватную современным институциональным макроэкономическим условиям государственную денежно-кредитную политику [4, с. 57]; Современные направления и формы финансирования реального сектора экономикиуниверситета. - 2015. - № 3 (87). - С. 73-78.

\section{Литература:}

1. Шумаев В.А., Морковкин Д.Е., Незамайкин В.Н., Юрзинова И.Л. Организационно-экономические аспекты управления инновационным развитием промышленности // Механизация строительства. - 2015. - № 3 (849). - C. 53-59. 